\title{
Increased p63 expression in canine perianal gland tumours
}

\author{
Soo-Hyeon Kim ${ }^{1}$, Byung-Joon Seung ${ }^{1}$, Seung-Hee Cho ${ }^{1}$, \\ Ha-Young Lim ${ }^{1}$, Hee-Myung Park ${ }^{2}$, Jung-Hyang Sur ${ }^{1}$ \\ ${ }^{1}$ Small Animal Tumour Diagnostic Centre, Department of Veterinary Pathology, \\ ${ }^{2}$ Department of Veterinary Internal Medicine, College of Veterinary Medicine, \\ Konkuk University, 05029, Seoul, Republic of Korea \\ jsur@konkuk.ac.kr
}

Received: December 22, 2017 Accepted: May 23, 2018

\begin{abstract}
Introduction: p63 is a homologous molecule of p53 and was recently identified as playing important roles in several key cellular processes, including epithelial development and proliferation. Since then, several studies have demonstrated altered p63 expression in various cancers of epithelial origin. Canine perianal gland tumour is one of the most common skin neoplasms in dogs; however, the molecular characteristics of this tumour remain poorly understood. The objective of the present study was to analyse and compare the expression of p63 in canine perianal gland adenomas and carcinomas. Material and Methods: Haematoxylin and eosin-stained slides were examined and immunohistochemistry was conducted for a total of 65 samples. Immunohistochemical data for p63 expressions were compared between groups using the Mann-Whitney U test. Results: The p63 expression level was increased in perianal gland carcinomas compared to that in the adenoma samples $(\mathrm{P}<0.0001)$. The percentage of cells expressing p63 was higher in perianal gland carcinomas than in adenomas, although the intensity of immunostaining did not differ significantly between the two groups. Conclusion: p63 is a candidate factor contributing to the malignant transformation and progression of canine perianal gland tumours.
\end{abstract}

Keywords: dog, perianal gland tumour, p63, immunohistochemistry.

\section{Introduction}

A recently identified homologue of $\mathrm{p} 53$ designated p63 has been shown to be highly expressed in the basal or progenitor layers of many epithelial tissues. In addition, p63 has been found to play various essential roles in cellular processes, including epithelial development, morphogenesis, proliferation, and differentiation (18). In this context, many researchers have focused on determining the p63 expression profiles in diverse kinds of cancers, and conflicting results have been obtained. This protein is overexpressed in many tumour cells or tissues, although the loss of its expression has also been detected in other studies. These discrepant results may be due to the presence of multiple p63 isoforms with opposing functions that can act as both oncogenes and tumour repressors (3).

To date, p63 expression has been evaluated in various tumour tissues of dogs, including mammary gland tumour, salivary gland tumour, or oral squamous cell carcinoma $(1,4,8)$. Normal mammary gland and benign myoepithelial cell tumours showed almost $100 \%$ immunoreactivity to $\mathrm{p} 63$ while a decrease was observed in malignant counterparts (4). The level of p63 expression in salivary gland carcinomas was variable and depended on tumour type (1), in contrast to oral squamous cell carcinoma cases, which showed $100 \%$ of p63 staining (8).

The perianal glands are ductless, modified sebaceous glands with uncertain function. Canine perianal gland tumour, also referred to as circumanal gland tumour or hepatoid gland tumour, is a unique neoplasm in the Canidae, and represents the most common type of cancer in the perineum of dogs (5). In spite of its relatively high incidence, information about the perianal gland itself and research on tumours of this region are very limited. Saraiva et al. (15) examined the p63 expression in cancers of canine skin appendages including perianal gland carcinomas. 
However, the small sample $(n=10)$ and lack of a control group in the study made it difficult to reveal the expression tendency in different types of perianal gland tumour tissues.

To fill this knowledge gap, the present study analysed the expression of p63 in canine perianal gland tumours and indirectly examined its role in canine perianal gland tumourigenesis.

\section{Material and Methods}

Tissue samples and patient data. Formalin-fixed paraffin-embedded (FFPE) tissues and patient data including sex, age, and breed were retrieved from the 2011-2017 archives of Konkuk University Veterinary Medical Diagnostic Laboratory (Small Animal Tumour Diagnostic Centre) (Table 1). As body condition score (BCS) data evaluated by clinicians were not available for the majority of the patients, body weights were retrieved and used as approximate supposition of the BCS. A total of 67 samples, including normal perianal glands $(n=2)$, perianal gland adenomas $(n=33)$, and perianal gland carcinomas $(n=32)$, were sectioned and stained with haematoxylin and eosin (H\&E). The slides were examined histopathologically and classified based on the World Health Organisation classification system (6).

Immunohistochemistry. FFPE tissues were sectioned at $4 \mu \mathrm{m}$, deparaffinised in xylene, hydrated in graded ethanol, and washed in phosphate-buffered saline. Endogenous peroxidase activity was blocked by incubating the tissue sections in 3\% hydrogen peroxide for $20 \mathrm{~min}$ at room temperature. Heat-induced antigen retrieval was carried out by boiling sections in citric acid buffer ( $\mathrm{pH} \mathrm{6.0)}$ ) for $8 \mathrm{~min}$. To reduce non-specific staining, sections were incubated with $5 \%$ normal goat serum for $30 \mathrm{~min}$ at room temperature. Sections were then incubated with the primary antibody for p63 (4A4, Santa Cruz, USA) in a dilution of $1: 200$ at room temperature for $3 \mathrm{~h}$. Secondary antibodies were applied using a ready-to-use-peroxidase-based kit (Agilent, USA), and sections were incubated for $40 \mathrm{~min}$ at room temperature. After washing steps, horse radish peroxidase (HRP) and 3,3'-diaminobenzidine were used for visualisation, and the sections were counterstained with Gill's haematoxylin, dehydrated in ethanol, and cover-slipped. Normal canine mammary gland sections were used as positive control samples based on a previous study (4), and negative controls were obtained using a mouse $\operatorname{IgG}_{2 \mathrm{a}}$ isotype control antibody instead of the p63 primary antibody.

Scoring of immunohistochemistry. Slides were analysed based on previously suggested criteria using the percentage of tumour cells with stained nucleus (0, negative or $<10 \% ; 1,10 \%-24 \% ; 2,25 \%-49 \%$; $3,50 \%-74 \%$; and $4, \geq 75 \%$ ) and intensity of staining (0, absent; 1, weak; 2, moderate; and 3, strong) (9).
Total scores were derived from the sum of the percentage score and intensity score (0-7). Data from the normal perianal gland samples were not included in the statistical analysis, but were evaluated for the establishment of the "baseline" expression level of p63 for comparative purposes.

Western blotting. Western blotting was conducted for primary antibody validation. Tissues were separated before FFPE procedures and stored at $-80^{\circ} \mathrm{C}$. After the confirmation of p63 expression through immunohistochemistry, p63 expressing tissues were selected for western blotting. Tissues were homogenised and proteins were extracted from those tissues using a radioimmunoprecipitation assay (RIPA) lysis buffer. Sodium dodecyl sulphate-polyacrylamide gel electrophoresis was carried out and the gel was transferred to a polyvinylidene difluoride membrane. The blot was incubated with 5\% skim milk for $1 \mathrm{~h}$, followed by incubation with 1:400 diluted p63 antibody in $2 \%$ skim milk for $2 \mathrm{~h}$ at room temperature. Diluted HRP-conjugated anti-mouse secondary antibody (ThermoScientific, USA) was applied to the blot for $1 \mathrm{~h}$ and the signals were detected using a chemiluminescent substrate (ThermoScientific).

Statistical analysis. To test the normality of the data, a Kolmogorov-Smirnov test was performed using SPSS 22.0 (IBM, USA). As the test rejected the null hypothesis, a Mann-Whitney $U$ test was conducted to compare data among the groups. $\mathrm{P}$ value of $<0.05$ was considered statistically significant.

\section{Results}

Clinicopathological data of patients. The breeds of the dogs included Shih-tzu (24.6\%); Maltese and mongrel dogs (12.3\% each); Cocker Spaniel, Jindo, and Yorkshire terrier $(6.2 \%$ each); Miniature Poodle and Schnauzer (4.6\% each); Dachshund, Pekinese, and Siberian Husky (3.1\% each); and Afghan Hound, Alaskan Malamute, beagle, Caucasian Ovcharka, Miniature Pinscher, Pungsan, and Toy Fox Terrier (1.5\% each). The breed of two dogs was unknown. In adenoma groups, the dogs were predominantly intact males $(66.7 \%)$, followed by spayed females (18.2\%), and intact females $(9.1 \%)$. Sex information was not available for two dogs (6.1\%). In carcinoma groups, the majority of the dogs were also intact males $(50.0 \%)$ and castrated males $(34.4 \%)$. Intact and spayed females comprised $9.4 \%$ and $3.1 \%$ of the patients, respectively. One dog's sex had not been recorded (3.1\%). The overall mean age of the dogs was 10.25 years; carcinoma patients had a higher mean age (11.84 years) than adenoma patients (10.69 years). Sites of neoplasms were predominantly the perianal region $(89.2 \%)$, prepuce $(6.2 \%)$, and tail $(3.1 \%)$. Location data had been omitted for one $\operatorname{dog}(1.5 \%)$. 
Table 1. Clinical data of dogs with tumours

\begin{tabular}{|c|c|c|c|c|c|c|c|c|c|c|c|}
\hline Adenoma & Breed & Sex & $\begin{array}{l}\text { Age } \\
\text { (years) }\end{array}$ & $\begin{array}{l}\mathrm{BCS} \\
(\mathrm{BW})\end{array}$ & Location & Carcinoma & Breed & Sex & $\begin{array}{l}\text { Age } \\
\text { (years) }\end{array}$ & $\begin{array}{l}\mathrm{BCS} \\
(\mathrm{BW})\end{array}$ & Location \\
\hline 1 & Pekinese & IM & 12 & $\mathrm{~N} / \mathrm{A}$ & Perianal & 1 & Shih-Tzu & $\mathrm{CM}$ & 5 & $\begin{array}{l}\text { N/A } \\
(5.7 \mathrm{~kg})\end{array}$ & Perianal \\
\hline 2 & Shih-Tzu & Unk & 8 & N/A & Perianal & 2 & Mongrel & IM & 14 & 4 & Perianal \\
\hline 3 & Pungsan & $\mathrm{IM}$ & 9 & $\begin{array}{l}\text { N/A } \\
(35 \mathrm{~kg})\end{array}$ & Perianal & 3 & $\begin{array}{l}\text { Yorkshire } \\
\text { Terrier }\end{array}$ & $\mathrm{IM}$ & 12 & 3 & Perianal \\
\hline 4 & $\begin{array}{l}\text { Alaskan } \\
\text { Malamute }\end{array}$ & $\mathrm{IM}$ & 10 & $\begin{array}{l}\text { N/A } \\
(60 \mathrm{~kg})\end{array}$ & Perianal & 4 & $\begin{array}{l}\text { Cocker } \\
\text { Spaniel }\end{array}$ & SF & 13 & N/A & Prepuce \\
\hline 5 & Maltese & $\mathrm{SF}$ & 10 & $\begin{array}{l}\mathrm{N} / \mathrm{A} \\
(3.2 \mathrm{~kg})\end{array}$ & Perianal & 5 & Schnauzer & IM & 8 & N/A & Tail \\
\hline 6 & $\begin{array}{l}\text { Miniature } \\
\text { Poodle }\end{array}$ & $\mathrm{IM}$ & 8 & $\begin{array}{l}\mathrm{N} / \mathrm{A} \\
(4.5 \mathrm{~kg})\end{array}$ & Perianal & 6 & Shih-Tzu & $\mathrm{CM}$ & 14 & 4 & Perianal \\
\hline 7 & Mongrel & $\mathrm{IM}$ & 8 & N/A & Perianal & 7 & $\begin{array}{l}\text { Cocker } \\
\text { Spaniel }\end{array}$ & $\mathrm{IM}$ & 10 & 3 & Perianal \\
\hline 8 & Maltese & $\mathrm{IM}$ & 11 & $\begin{array}{l}\text { N/A } \\
(3.16 \mathrm{~kg})\end{array}$ & Perianal & 8 & Mongrel & $\mathrm{CM}$ & 12 & N/A & Prepuce \\
\hline 9 & $\begin{array}{l}\text { Miniature } \\
\text { Poodle }\end{array}$ & $\mathrm{IM}$ & 13 & 4 & Perianal & 9 & $\begin{array}{l}\text { Cocker } \\
\text { Spaniel }\end{array}$ & $\mathrm{CM}$ & 12 & $\begin{array}{l}\text { N/A } \\
(16 \mathrm{~kg})\end{array}$ & Perianal \\
\hline 10 & Maltese & IF & 11 & 4 & Perianal & 10 & Maltese & $\mathrm{CM}$ & Unk & 3 & Perianal \\
\hline 11 & Jindo & $\mathrm{IM}$ & 10 & 3 & Perianal & 11 & Shih-Tzu & $\mathrm{IM}$ & 12 & $\begin{array}{l}\text { N/A } \\
(7 \mathrm{~kg})\end{array}$ & Perianal \\
\hline 12 & Unk & $\mathrm{SF}$ & 14 & N/A & Perianal & 12 & Shih-Tzu & $\mathrm{CM}$ & 12 & $\begin{array}{l}\mathrm{N} / \mathrm{A} \\
(9.7 \mathrm{~kg})\end{array}$ & Perianal \\
\hline 13 & Dachshund & $\mathrm{IM}$ & 13 & $\begin{array}{l}\mathrm{N} / \mathrm{A} \\
(6.8 \mathrm{~kg})\end{array}$ & Perianal & 13 & Jindo & $\mathrm{IM}$ & 7 & 3 & Perianal \\
\hline 14 & Schnauzer & SF & 13 & $\begin{array}{l}\mathrm{N} / \mathrm{A} \\
(6.9 \mathrm{~kg})\end{array}$ & Perianal & 14 & Shih-Tzu & $\mathrm{CM}$ & 10 & N/A & Perianal \\
\hline 15 & Jindo & $\mathrm{IM}$ & 14 & $\begin{array}{l}\text { N/A } \\
(18 \mathrm{~kg})\end{array}$ & Perianal & 15 & $\begin{array}{l}\text { Cocker } \\
\text { Spaniel }\end{array}$ & IF & 12 & $\begin{array}{l}\text { N/A } \\
(11.5 \mathrm{~kg})\end{array}$ & Perianal \\
\hline 16 & $\begin{array}{l}\text { Siberian } \\
\text { Husky }\end{array}$ & IM & 10 & $\begin{array}{l}\text { N/A } \\
(40 \mathrm{~kg})\end{array}$ & Perianal & 16 & Jindo & $\mathrm{IM}$ & 12 & $\begin{array}{l}\text { N/A } \\
(9.1 \mathrm{~kg})\end{array}$ & Perianal \\
\hline 17 & Shih-Tzu & $\mathrm{SF}$ & 14 & 5 & Perianal & 17 & $\begin{array}{l}\text { Miniature } \\
\text { Poodle }\end{array}$ & $\mathrm{CM}$ & 11 & 3 & Perianal \\
\hline 18 & Schnauzer & $\mathrm{IM}$ & 13 & $\begin{array}{l}\text { N/A } \\
(9.3 \mathrm{~kg})\end{array}$ & Perianal & 18 & Unk & $\mathrm{IM}$ & 15 & Unk & Prepuce \\
\hline 19 & Pekinese & IM & 12 & $\begin{array}{l}\text { N/A } \\
(16 k g)\end{array}$ & Perianal & 19 & $\begin{array}{l}\text { Toy Fox } \\
\text { Terrier }\end{array}$ & $\mathrm{SF}$ & 13 & 4 & Perianal \\
\hline 20 & Shih-Tzu & $\mathrm{IM}$ & 11 & $\begin{array}{l}\text { N/A } \\
(6 \mathrm{~kg})\end{array}$ & Perianal & 20 & Shih-Tzu & $\mathrm{IM}$ & 13 & $\begin{array}{l}\text { N/A } \\
(7.6 \mathrm{~kg})\end{array}$ & Perianal \\
\hline 21 & $\begin{array}{l}\text { Caucasian } \\
\text { Ovcharka }\end{array}$ & IF & 12 & 4 & Perianal & 21 & Maltese & IM & 10 & 3 & Perianal \\
\hline 22 & $\begin{array}{l}\text { Miniature } \\
\text { Pinscher }\end{array}$ & IM & 10 & $\begin{array}{l}\mathrm{N} / \mathrm{A} \\
(8.3 \mathrm{~kg})\end{array}$ & Perianal & 22 & Shih-Tzu & $\mathrm{IM}$ & 15 & N/A & Perianal \\
\hline 23 & Maltese & SF & 8 & N/A & Perianal & 23 & Shih-Tzu & $\mathrm{CM}$ & 12 & 4 & Perianal \\
\hline 24 & $\begin{array}{l}\text { Siberian } \\
\text { Husky }\end{array}$ & IM & 10 & $\begin{array}{l}\text { N/A } \\
(40 \mathrm{~kg})\end{array}$ & Perianal & 24 & $\begin{array}{l}\text { Yorkshire } \\
\text { Terrier }\end{array}$ & $\mathrm{CM}$ & 14 & 3 & Perianal \\
\hline 25 & Shih-Tzu & $\mathrm{IM}$ & 11 & $\begin{array}{l}\text { N/A } \\
(7.15 \mathrm{~kg})\end{array}$ & Perianal & 25 & Mongrel & IM & 10 & 3 & Perianal \\
\hline 26 & Mongrel & Unk & 13 & N/A & Tail & 26 & Shih-Tzu & Unk & 11 & $\begin{array}{l}\mathrm{N} / \mathrm{A} \\
(6.8 \mathrm{~kg})\end{array}$ & Perianal \\
\hline 27 & Mongrel & IF & 7 & 3 & Perianal & 27 & Shih-Tzu & $\mathrm{IM}$ & 12 & $\begin{array}{l}\text { N/A } \\
(6.7 \mathrm{~kg})\end{array}$ & Perianal \\
\hline 28 & Maltese & $\mathrm{SF}$ & 10 & $\begin{array}{l}\text { N/A } \\
(3.1 \mathrm{~kg})\end{array}$ & Perianal & 28 & Maltese & $\mathrm{IM}$ & 11 & $\begin{array}{l}\text { N/A } \\
(4.6 \mathrm{~kg})\end{array}$ & Prepuce \\
\hline 29 & Shih-Tzu & $\mathrm{IM}$ & 9 & $\begin{array}{l}\text { N/A } \\
(10 k g)\end{array}$ & Perianal & 29 & Mongrel & $\mathrm{CM}$ & 13 & 3 & Perianal \\
\hline 30 & Mongrel & $\mathrm{IM}$ & 10 & N/A & Tail & 30 & $\begin{array}{l}\text { Yorkshire } \\
\text { Terrier }\end{array}$ & $\mathrm{IM}$ & 14 & N/A & Perianal \\
\hline 31 & $\begin{array}{l}\text { Afghan } \\
\text { Hound }\end{array}$ & $\mathrm{IM}$ & 9 & 3 & Perianal & 31 & $\begin{array}{l}\text { Yorkshire } \\
\text { Terrier }\end{array}$ & $\mathrm{SF}$ & 13 & N/A & Perianal \\
\hline 32 & Dachshund & $\mathrm{IM}$ & 10 & N/A & Unk & 32 & Shih-Tzu & $\mathrm{IM}$ & 15 & $\begin{array}{l}\mathrm{N} / \mathrm{A} \\
(8.9 \mathrm{~kg})\end{array}$ & Perianal \\
\hline 33 & Beagle & $\mathrm{IM}$ & 10 & 3 & Perianal & & & & & & \\
\hline
\end{tabular}

Unk - unknown, IM - intact male, CM - castrated male, IF - intact female, SF - spayed female $\mathrm{BCS}$ - body condition score, BW - body weight

Histopathological classification of perianal tumours. Perianal gland adenomas comprised perianal gland cells with an abundant amount of eosinophilic cytoplasm. The tumour cells formed typically welldemarcated lobules, cords, and islands surrounded by a layer of small basophilic reserve cells (Fig. 1A). 
Sebaceous or ductal differentiation was observed in some samples. Contrastingly, in perianal gland carcinomas perianal gland cells and basaloid reserve cells were rarely distinguishable. Lobules were disrupted and tumour cells with nuclear atypia and little cytoplasm densely proliferated in disorganised patterns (Fig. 1B).

Immunohistochemistry. The results of immunohistochemistry for p63 are presented in Figs 2 to 4. All immunostained cells showed a distinct nuclear staining pattern. The expression of p63 based on the total score was significantly higher in the perianal gland carcinomas than in adenomas $(\mathrm{P}<0.0001)$. The percentages of stained cells were also significantly higher $(\mathrm{P}<0.0001)$ for the perianal gland carcinomas than adenomas, whereas the intensity scores did not differ significantly between the two tumour types $(\mathrm{P}=0.083)$. The baseline expression levels of $\mathrm{p} 63$ in the two normal perianal glands were similar to those of adenomas in terms of both percentage and intensity. Positive control sections (normal mammary gland tissues) also demonstrated a distinct nuclear expression pattern of p63 in myoepithelial cells and no staining was detected in the negative control tissues.

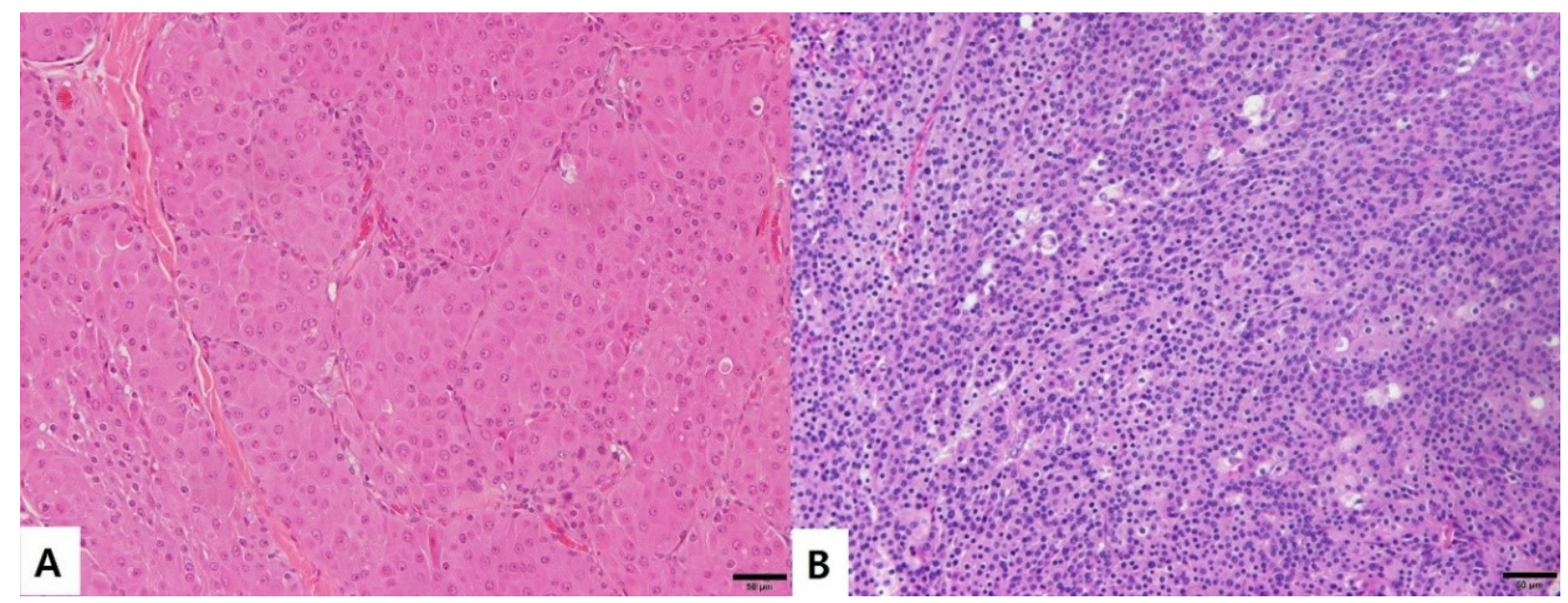

Fig. 1. Histopathological classification of perianal gland tumours $(200 \times)$. Perianal gland adenoma is characterised by lobules and cords separated by a layer of basaloid reserve cells (A) and perianal gland carcinoma shows disrupted lobules and disorderly proliferated tumour cells (B)

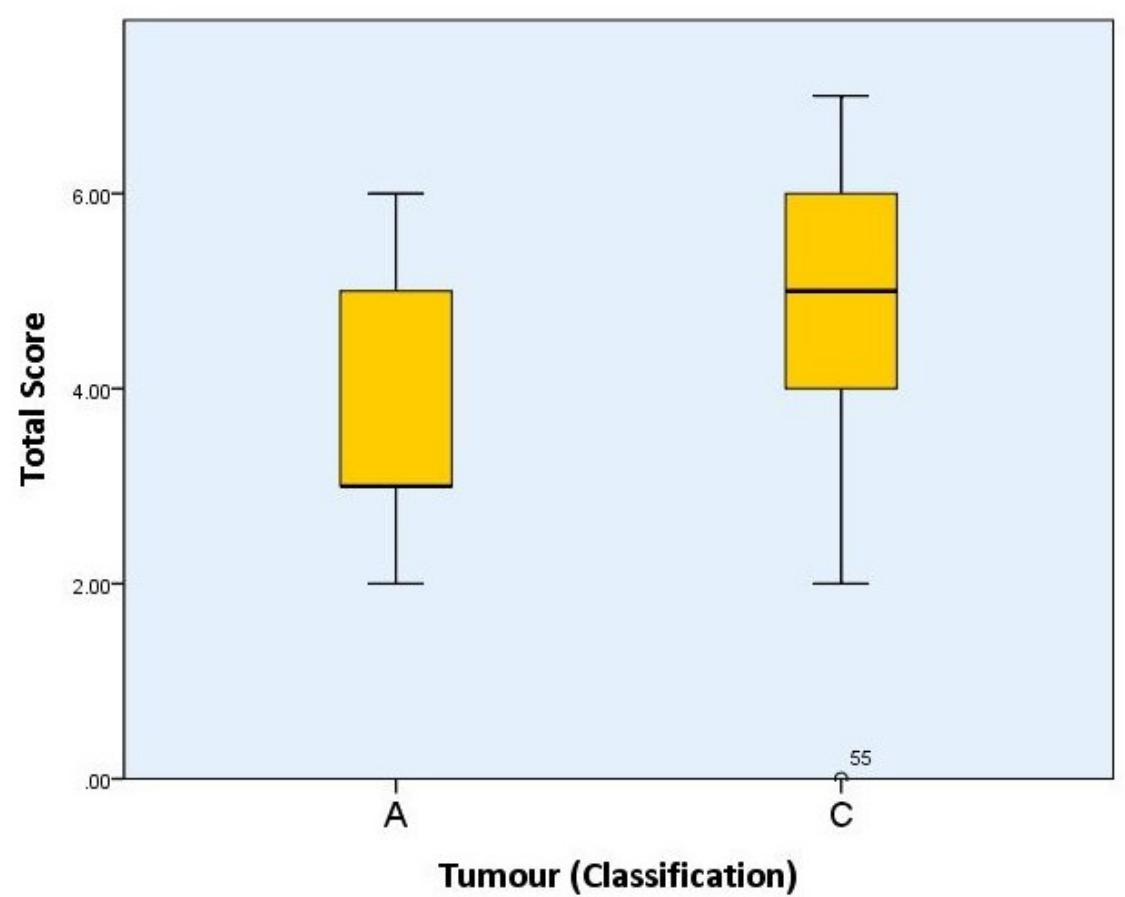

Fig. 2. Box plot analysis of total expression score of p63 in perianal gland adenoma (A) and carcinoma (C) samples 


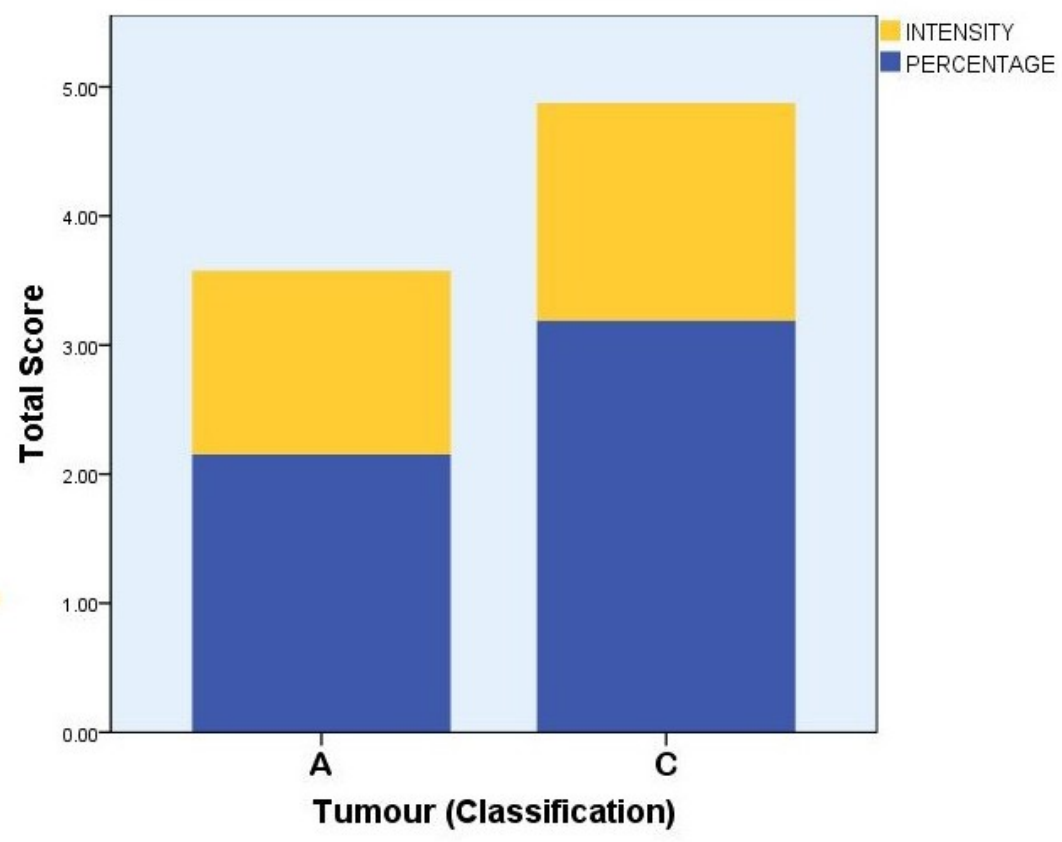

Fig. 3. Mean value of total score, percentage of p63 of stained cells (blue bars), and intensity levels (yellow bars) of p63 in perianal gland adenoma (A) and carcinoma (C) samples

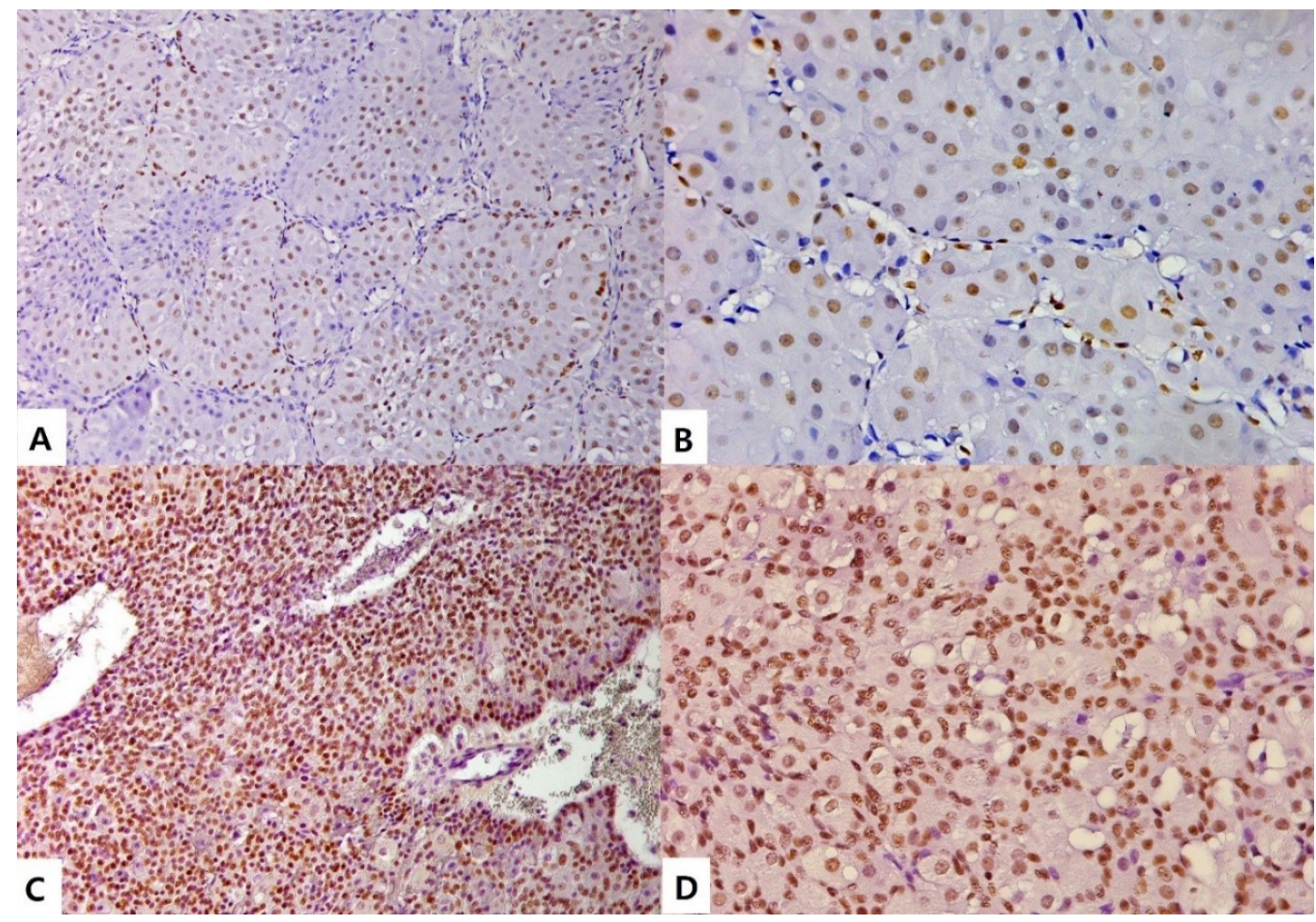

Fig. 4. Immunohistochemistry of p63 in canine perianal gland tumour tissues; A - p63 expression in perianal gland adenoma $(200 \times)$, B - p63 expression in perianal gland adenoma $(400 \times), \mathrm{C}-\mathrm{p} 63$ expression in perianal gland carcinoma $(200 \times), D-p 63$ expression in perianal gland carcinoma $(400 \times)$

Western blotting. Western blotting for p63 antibody showed a single distinct band in each sample, identifying its specificity on perianal gland tumour tissues (Fig. 5). Protein samples in lanes 1-2 were from perianal gland adenomas and in lanes 3-6 were from perianal gland carcinomas. Band size was around $55 \mathrm{kDa}$, consistent with the molecular weights of
$\Delta \mathrm{Np} 63$ isoforms $(55-62 \mathrm{kDa}$ for $\Delta \mathrm{Np} 63 \beta ; 47-53 \mathrm{kDa}$ for $\Delta \mathrm{Np} 63 \gamma(13))$.

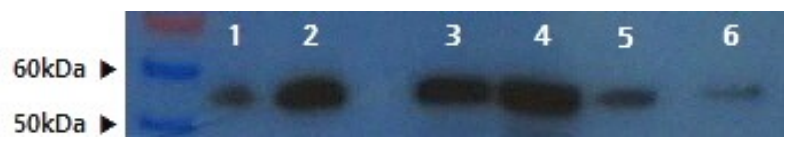

Fig. 5. Western blotting for p63 antibody validation 


\section{Discussion}

TP63 gene is expressed through complex alternative splicing processes, resulting in six isoforms of p63, with TAp63 and $\Delta \mathrm{Np} 63$ as the dominant forms (13). Although both isoforms are associated with carcinogenesis and tumour progression, several studies have shown that the TAp63 isoform is related to cellular senescence and apoptosis, whereas the $\Delta \mathrm{Np} 63$ isoform can promote cell survival and proliferation (2).

Altered expression of p63 has been reported in many human cancers of epithelial origin such as breast cancer, squamous cell carcinoma, and lung cancer. However, many of these clinical reports did not consider the complex alternative splicing variants of p63, which have been revealed to have different functions (7). Most immunohistochemical studies used the original primary antibody obtained against $\Delta \mathrm{Np} 63$ isoform, p63 antibody clone 4A4. However, 4A4 has been revealed not to be able to distinguish six p63 isoforms even though it was developed to the $\Delta \mathrm{Np} 63$ isoform, because it recognises the non-characteristic central site of all p63 isoforms (11). Therefore, the results of the present study cannot distinguish the specific isoform of p63. Nevertheless, the results of the present study show a distinct band on western blotting despite the known non-specificity of the antibody. This may be due to the long half-life of $\Delta \operatorname{Np} 63 \gamma(>8 \mathrm{~h})$ while other isoforms have a short half-life $(<1 \mathrm{~h})$ (13); thus, remaining $\Delta \mathrm{Np} 63 \gamma$ is captured through immunohistochemistry and western blotting. Molecular weights also corresponded with $\Delta \mathrm{Np} 63 \gamma(47-53 \mathrm{kDa})$ (13). Therefore, these results may reflect the presence of $\Delta \mathrm{Np} 63 \gamma$ in perianal gland carcinoma tissues, with high potency to proliferate and survive in comparison to perianal gland adenoma; however, the exact isoform expression should be further studied.

Overall, the results of the present study showed an increased percentage of malignant tumour cells expressing p63. Thus, dysregulation or overexpression of $\mathrm{p} 63$ could be the key feature of actively proliferating perianal gland tumour cells. A previous report indicated that perianal gland adenomas and carcinomas do not express p53. The accumulation and immune-labelling of p53 occur when there is a mutation in the p53 gene, because the half-life of p53 is normally short and therefore it is removed too rapidly to be detected (10). Therefore, mutation of the p53 gene does not seem to occur in perianal gland neoplasms, whereas altered expression of its homologue p63 might instead explain this malignant transformation and progression.

Perianal gland tumour shows androgen dependence; thus, castration has been successful in promoting regression without recurrence, even without excision of the tumour mass in cases of perianal gland adenoma (17). Indeed, perianal gland tumour is more common in aged, intact male dogs and occurs less frequently in female and castrated dogs (12). This general situation was also reflected by the age and sex distribution of the dogs included in the present study.
Nevertheless, the proportion of castrated males in dogs with perianal gland carcinoma was rather high (34.4\%) compared to that in dogs with perianal gland adenomas $(0 \%)$. In addition, one study demonstrated that androgen receptor expression in perianal gland tumour tissues was only slightly higher than that of normal perianal gland tissues (14). Based on these findings, it could be hypothesised that androgen stimulates normal perianal gland continuously to spontaneously change into preneoplastic lesion or adenoma during the dog's lifetime. Consequently, adenoma mainly occurs in intact male dogs. On the other hand, dogs are castrated at different times in their life, and induced preneoplastic lesion or adenoma returns to a normal-like perianal gland, thus perianal gland adenoma does not occur. However, if another molecular change - such as p63 - stimulates the perianal gland, malignant transformation of perianal gland cells may occur independently of an androgen-related cause. The same process could happen also in intact male dogs with preneoplastic lesion or adenoma. Thus, change of p63 expression causes malignant neoplasm to occur equally in intact males and castrated males, as the sex distribution demonstrated in present study. However, this discrepant result might just stem from sample numbers being too low to represent perianal gland tumour patients generally.

The perianal gland was extensively studied in the 1920s and 1930s. However, mistakes were often repeated in literature, from the $1950 \mathrm{~s}$ to the present, and some of the original information related to perianal glands has been completely lost (16). Therefore, even though perianal gland tumour is very common in dogs, data about the gland itself and neoplasms occurring in this structure remain relatively sparse. Thus, further study is needed to obtain an advanced understanding the formation and progression of perianal gland neoplasms, including further focus on the role of $\mathrm{p} 63$.

Conflict of Interests Statement: The authors declare that there is no conflict of interests regarding the publication of this article.

Financial Disclosure Statement: This research was supported by the Bio and Medical Technology Development Program of the National Research Foundation (NRF) and funded by the Korean government (MSIT) (2016M3A9B6903437).

Animal Rights Statement: The authors declare that the experiments on animals were conducted in accordance with local Ethical Committee laws and regulations as regards care and use of laboratory animals.

Acknowledgements: The authors show appreciation to Mrs. Yu for the technical support. 


\section{References}

1. Abd Raboh N.M., Hakim S.A.: Diagnostic role of DOG1 and p63 immunohistochemistry in salivary gland carcinomas. Int $\mathrm{J}$ Clin Exp Pathol 2015, 8, 9214-22.

2. Berghloz J., Xiao Z.X.: Role of p63 in development, tumorigenesis, and cancer progression. Cancer Microenviron 2012, doi: 10.1007/s12307-012-0116-9.

3. Flores E.R.: The roles of p63 in cancer. Cell Cycle 2007, doi: 10.4161/cc.6.3.3793.

4. Gama A., Alves A., Gartner F., Schmitt F.: p63: a novel myoepithelial cell marker in canine mammary tissues. Vet Pathol 2003, doi: 10.1354/vp.40-4-412.

5. Goldschmidt M.H., Goldschmidt K.H.: Epithelial and melanocytic tumors of the skin. In: Tumors in Domestic Animals, edited by Meuten D.J., John Wiley \& Sons, New Jersey, 2016, pp. 113-115.

6. Goldschmidt M.H., Dunstan R.W., Stannard A.A., Tscharner C.V., Walder E.J., Yager J.A.: Histological classification of epithelial and melanocytic tumors of the skin of domestic animals. WHO International Classification of Tumors of Domestic Animals, vol. 3, Armed Forces Institute of Pathology, Washington, 1998, pp. 27-28.

7. Graziano V., De Laurenzi V.: Role of p63 in cancer development. Biochim Biophys Acta 2011, doi: 10.1016/j.bbcan.2011.04.002.

8. Mestrinho L.A., Pissarra H., Faisca P.B., Braganca M., Peleteiro M.C., Niza M.M.: p63 and E-cadherin expression in canine oral squamous cell carcinoma. Vet Pathol 2015, 52, 614-620.

9. Monteiro L.S., Delgado M.L., Ricardo S., do Amaral B., Salazar F., Pacheco J.J., Lopes C.A., Bousbaa H., Warbajykasyriya S.: Prognostic significance of CD44v6, p63, podoplanin, and MMP-9 in oral squamous cell carcinomas. Oral Dis 2016, doi: 10.1111/odi.12442.

10. Nakano M., Taura Y., Inoue M.: Protein expression of Mdm2 and $\mathrm{p} 53$ in hyperplastic and neoplastic lesions of the canine circumanal gland. J Comp Pathol 2005, doi: 10.1016/j.jcpa.2004.06.001.

11. Nekulova M., Holcakova J., Nenutil R., Stratmann R., Bouchalova P., Muller P., Moukova L., Coates P.J., Vojtesek B.: Characterization of specific p63 and p-63-N-terminal isoform antibodies and their application for immunohistochemistry. Virchows Arch 2013, 463, 415-425.

12. Pereira R.S., Schweigert A., Dias de Melo G., Fernandes F.V., Sueiro F.A., Machado G.F.: Ki-67 labelling in canine perianal glands neoplasms: a novel approach for immunohistological diagnostics and prognostic. BMC Vet Res 2013, doi: 10.1186/1746-6148-9-83.

13. Petitjean A., Ruptier C., Tribollet V., Hautefeuille A., Chardon F., Cavard C., Puisieux A., Hainaut P., Caron de Fromentel C.: Properties of the six isoforms of p63: p53-like regulation in response to genotoxic stress and cross talk with DeltaNp73. Carcinogenesis 2008, 29, 273-281.

14. Pisani G., Millanta F., Lorenzi D., Vannozzi I., Poli A.: Androgen receptor expression in normal, hyperplastic and neoplastic hepatoid glands in the dogs. Res Vet Sci 2006, doi: 10.1016/j.rvsc.2005.11.001

15. Saraiva A.L., Gartner F., Pires M.A.: Expression of p63 normal canine skin and primary cutaneous glandular carcinomas. Vet $\mathrm{J}$ 2008, 177, 136-140.

16. Shabadash S.A., Zelikina T.I.: Once more about hepatoid circumanal glands of dogs. History of their discovery and reasons for revision the structural and functional data. Iza Akad Nauk Ser Biol 2002, 2, 176-185.

17. Wilson G.P., Hayes H.M. Jr.: Castration for treatment of perianal gland neoplasms in the dog. J Am Vet Med Assoc 1979, 174, 1301-1303.

18. Yang A., Schweitzer R., Sun D., Kaghad M., Walker N., Bronson R.T., Tabin C., Sharpe A., Caput D., Crum C., McKeon F.: p63 is essential for regenerative proliferation in limb, craniofacial, and epithelial development. Nature 1999, doi: 10.1038/19539. 